\title{
Novel Technologies to Enhance Energy Performance and Indoor Environmental Quality of Buildings
}

\author{
Alessandro Cannavale ${ }^{1,2, *(\mathbb{D}}$, Francesco Martellotta ${ }^{1}(\mathbb{D})$ and Francesco Fiorito ${ }^{3} \mathbb{D}$ \\ 1 Department of Civil Engineering Sciences and Architecture, Polytechnic University of Bari, 70126 Bari, Italy; \\ francesco.martellotta@poliba.it \\ 2 National Research Council, Institute of Nanotechnology (CNR-NANOTEC), Via Monteroni, 73100 Lecce, Italy \\ 3 Department of Civil, Environmental, Land, Building Engineering and Chemistry, Polytechnic University of \\ Bari, 70126 Bari, Italy; francesco.fiorito@poliba.it \\ * Correspondence: alessandro.cannavale@poliba.it; Tel.: +39-080-596-3718
}

check for

updates

Citation: Cannavale, A.; Martellotta, F.; Fiorito, F. Novel Technologies to Enhance Energy Performance and Indoor Environmental Quality of Buildings. Buildings 2021, 11, 303. https://doi.org/10.3390/buildings 11070303

Received: 8 July 2021

Accepted: 9 July 2021

Published: 11 July 2021

Publisher's Note: MDPI stays neutral with regard to jurisdictional claims in published maps and institutional affiliations.

Copyright: (c) 2021 by the authors. Licensee MDPI, Basel, Switzerland. This article is an open access article distributed under the terms and conditions of the Creative Commons Attribution (CC BY) license (https:// creativecommons.org/licenses/by/ $4.0 /)$.
Here, we overview the Buildings journal Special Issue dedicated to the following topic: "Novel Technologies to Enhance Energy Performance and Indoor Environmental Quality of Buildings" (https://www.mdpi.com/journal/buildings/special_issues/Energy_Indoor_ Environmental, last access on 7 July 2021) and the scientific papers it hosts. The aim of this Special Issue was to report current trends in the investigations dealing with emerging materials and devices, aiming at an increase in energy performance of buildings and indoor comfort. We are currently facing an epochal transition, involving a compelling change in the way we produce and use energy: in this roadmap, low impact buildings might play a relevant role. The enhancement of energy efficiency, in the construction sector, can be obtained by the development of new materials, with improved properties, spanning from chromogenics [1-3] to semitransparent photovoltaics [4-7], superinsulating materials [8,9], and phase change materials [10,11]. Novel technologies may also increase comfort, indoor environmental quality and safety as well. Ten original research studies have been published, with the contributions of international research groups, from Italy, Poland, Australia, United Kingdom, Croatia, Spain, and Taiwan. All these contributions address the main topics of the Special Issue, with an effective and targeted effort.

Cannavale et al. [12] proposed an innovative aerogel-based "thermal break" for window frames, to effectively reduce the frame conductance of regulation compliant reference windows. The thermal performance of this new window was assessed by finite element method. Furthermore, numerical simulations were carried out to assess energy savings for heating and cooling, for several international locations, confirming the potential of this novel building component, embodying super-insulating materials, which revealed its suitability for extremely rigid climates.

Mainka et al. [13] reported a study about homemade air purifiers, namely low-cost ozone generators to decrease the level of contaminants. In their experimental activity, they investigated the reduction of bacterial and fungal aerosol by using two available technological solutions of air purifiers. They observed a decrease by $78 \%$ of bacteria concentration, after $20 \mathrm{~min}$ of ozone generation. The authors of also point out that ozone has the property of destroying the coronavirus, at the basis of the global SARS-CoV-2 pandemic. This aspect could justify a particular interest in the proposed device.

Kuru et al. [14] investigated the possible transfer of multifunctionality in nature into biomimetic strategies for engineered systems, by creating an effective framework to develop multifunctional biomimetic adaptive building skins. Such a framework may become a systemic collection of biological information. Numerical simulations proposed a comparison between the base-case building and a case study, demonstrating a decrease of discomfort hours by $23.18 \%$. The authors proposed biomimetic design as a suitable approach for future buildings. 
Roy et al. [15] proposed a review paper dealing with perovskite solar cells, whose rapid worldwide diffusion in scientific research has attracted the attention of industries and governments. The authors investigated the main issues about building integration of perovskite-based solar cells, showing their main features, opportunities but also critical issues and current limits, which perhaps will soon be overcome, thanks to future scientific efforts.

Franco et al. [16] investigated the relevant role of ventilation rate, to achieve air quality in public buildings, with special attention to the required compromise between indoor air quality and the control of energy consumption. The authors proposed a method for the definition of optimal values of air exchange rates and found lower air flow exchange rates, compared to current Technical Standards, sensitive to occupation profiles. The authors claim that their adaptive solution represents a considerable progress, being based on simple measurements of carbon dioxide concentration, by means of commercial sensors.

Ćorić et al. [17] proposed a research article dealing with the application of seismic energy dissipaters based on a cost-effective copper-based shape memory alloy. The ausforming process was suitably optimized by controlling the parameters, achieving both adequate strength and suitable transformation behaviour.

Ciampi et al. [18] reported their experimental tests on extruded Acrylonitrile-ButadieneStyrene, used in form of panels as a second-skin layer in a ventilated building façade, to be applied in eight refurbishment cases, analysed by means of a numerical simulation software platform. In comparison to the reference case study, the proposed system allowed reduction of energy demand for heating $(-6.9 \%)$ and for cooling $(-3.1 \%)$.

Zsembinszki et al. [19] studied a Deep Reinforcement Learning architecture, able to solving complex control problems and applied it to the control of novel hybrid energy storage systems. They found that a suitable strategy may reduce the system operating costs of cooling by more than $50 \%$, in residential buildings located in the Mediterranean climate.

In their work, Morano et al. [20] focussed their attention on one of the most relevant environmental factors, affecting human health: noise pollution. Its effects on the real estate market were investigated, by analysing functional relationships between noise pollution and selling prices in the city of Bari, in Apulia (Italy).

Hwang et al. [21] investigated the energy saving potential due to the integration of Phase Change Materials in rooftops, so as to reduce indoor temperatures in schools of Taiwan. The ideal melting temperature was found to be $29^{\circ} \mathrm{C}$, whereas the effective thickness of the material was $20 \mathrm{~mm}$, for the selected locations, in Northern Taiwan.

The guest editors of this Special Issue would like to acknowledge all the authors for their scientific support and for kindly sharing their knowledge, from different fields of investigation. Furthermore, the editors would like to express their gratitude to the peer reviewers, for their rigorous analysis of manuscripts - effectively contributing to achieve the publication of the Special Issue - and the managing editors of Buildings, for their continuous support.

Author Contributions: All authors contributed to every part of this editorial. All authors have read and agree to the published version of the manuscript.

Funding: This research activity did not receive any funding.

Acknowledgments: The authors gratefully acknowledge Managing Editor of Buildings (MDPI) for her precious, professional support.

Conflicts of Interest: The authors declare no conflict of interest.

\section{References}

1. Lampert, C.M. Chromogenic smart materials. Mater. Today 2004, 7, 28-35. [CrossRef]

2. Cannavale, A. Chromogenic Technologies for Energy Saving. Clean Technol. 2020, 2, 29. [CrossRef]

3. Granqvist, C.G. Oxide-based chromogenic coatings and devices for energy efficient fenestration: Brief survey and update on thermochromics and electrochromics. J. Vac. Sci. Technol. B 2014, 32, 060801. [CrossRef] 
4. Hörantner, M.T.; Nayak, P.K.; Mukhopadhyay, S.; Wojciechowski, K.; Beck, C.; McMeekin, D.; Kamino, B.; Eperon, G.E.; Snaith, H.J. Shunt-Blocking Layers for Semitransparent Perovskite Solar Cells. Adv. Mater. Interfaces 2016, 3, 1500837. [CrossRef]

5. Della Gaspera, E.; Peng, Y.; Hou, Q.; Spiccia, L.; Bach, U.; Jasieniak, J.J.; Cheng, Y.B. Ultra-thin high efficiency semitransparent perovskite solar cells. Nano Energy 2015, 13, 249-257. [CrossRef]

6. $\quad$ Chen, C.C.; Dou, L.; Zhu, R.; Chung, C.H.; Song, T.B.; Zheng, Y.B.; Hawks, S.; Li, G.; Weiss, P.S.; Yang, Y. Visibly transparent polymer solar cells produced by solution processing. ACS Nano 2012, 6, 7185-7190. [CrossRef] [PubMed]

7. Cannavale, A.; Martellotta, F.; Fiorito, F.; Ayr, U. The challenge for building integration of highly transparent photovoltaics and photoelectrochromic devices. Energies 2020, 13, 1929. [CrossRef]

8. Berardi, U. The development of a monolithic aerogel glazed window for an energy retrofitting project. Appl. Energy 2015, 154, 603-615. [CrossRef]

9. Jelle, B.P. Traditional, state-of-the-art and future thermal building insulation materials and solutions-Properties, requirements and possibilities. Energy Build. 2011, 43, 2549-2563. [CrossRef]

10. Baetens, R.; Petter, B.; Gustavsen, A. Phase change materials for building applications: A state-of-the-art review. Energy Build. 2012, 42, 1361-1368. [CrossRef]

11. De Matteis, V.; Cannavale, A.; Martellotta, F.; Rinaldi, R.; Calcagnile, P.; Ferrari, F.; Ayr, U.; Fiorito, F. Nano-encapsulation of phase change materials: From design to thermal performance, simulations and toxicological assessment. Energy Build. 2019, 188-189, 1-11. [CrossRef]

12. Cannavale, A.; Martellotta, F.; Berardi, U.; Rubino, C.; Liuzzi, S.; Carlo, V.D.; Ayr, U. Modeling of an Aerogel-Based “Thermal Break" for Super-Insulated Window Frames. Buildings 2020, 10, 60. [CrossRef]

13. Mainka, A.; Mucha, W.; Janoszek, A. Non-commercial Air Purifier-The E ffectiveness and Safety. Buildings 2020, 10 , 104. [CrossRef]

14. Kuru, A.; Oldfield, P.; Bonser, S.; Fiorito, F. A framework to achieve multifunctionality in biomimetic adaptive building skins. Buildings 2020, 10, 114. [CrossRef]

15. Roy, A.; Ghosh, A.; Bhandari, S.; Sundaram, S.; Mallick, T.K. Perovskite solar cells for bipv application: A review. Buildings 2020, 10, 129. [CrossRef]

16. Franco, A.; Schito, E. Comfort and Energy Use in Indoor Spaces Using $\mathrm{CO}_{2}$. Buildings 2020, 10, 135. [CrossRef]

17. Ćorić, D.; Žmak, I. Influence of ausforming treatment on super elasticity of cu-zn-al shape memory alloy for seismic energy dissipaters. Buildings 2021, 11, 22. [CrossRef]

18. Ciampi, G.; Spanodimitriou, Y.; Scorpio, M.; Rosato, A.; Sibilio, S. Energy performances assessment of extruded and 3d printed polymers integrated into building envelopes for a south Italian case study. Buildings 2021, 11, 141. [CrossRef]

19. Zsembinszki, G.; David, V.; Cabeza, L.F. Deep Learning Optimal Control for a Complex Hybrid Energy Storage System. Buildings 2021, 11, 194. [CrossRef]

20. Morano, P.; Tajani, F.; Di Liddo, F.; Darò, M. Economic evaluation of the indoor environmental quality of buildings: The noise pollution effects on housing prices in the city of Bari (Italy). Buildings 2021, 11, 213. [CrossRef]

21. Hwang, R.-L.; Chen, B.-L.; Chen, W.-A. Analysis of Incorporating a Phase Change Material in a Roof for the Thermal Management of School Buildings in Hot-Humid Climates. Buildings 2021, 11, 248. [CrossRef] 